\title{
Artenografia e mitodologia em arte: práticas de fomento ao Ator de f(r)icção
}

\section{Art-ethnography and mythodology in art: practices to develop the $f(r)$ iction actor}

Luciana de Fatima Rocha Pereira de Lyra $^{1}$ 


\section{Resumo}

Nas investigações de mestrado e doutorado em Artes Cênicas (IA/UNICAMP) e pós doutorado em Antropologia (FFLCH/USP), a pesquisadora elaborou a Mitodologia em Arte, um complexo de procedimentos de cunhos ritualísticos e míticos, que estimulam a eclosão de pulsões pessoais dos artistas, aperfeiçoando o pluralismo das imagens colhidas nas experiências ditas artetnográficas. A Artetnografia, ideia também defendida pela investigadora, traduz-se pela operação de entrelaçamento entre eus (artistas) e contextos de alteridades (comunidades). A partir de experiências metodológicas / artetnográficas, foram criados os espetáculos Joana In Cárcere (2005), Guerreiras (2009) e Homens e caranguejos (2012), fomentando um terceiro conceito: o Ator

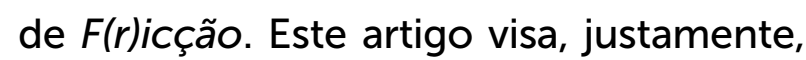
descortinar o percurso da pesquisadora na construção das citadas dramaturgias /encenações, por meio dessas práticas conceituais, e vem se constituir enquanto vestígio memorial da palestra ministrada durante a I Jornada de Pesquisa Mulheres em Cena, realizada em fevereiro de 2014, no Centro de Artes da Universidade Estadual de Santa Catarina (UDESC).

Palavras-Chave: Artetnografia; mitodologia em arte; ator de f(r)icção.

\section{Abstract}

Within the context of her graduate research (MA and PhD in Artes Cênicas at IA/UNICAMP) and post-doctoral research in Anthropology (FFLCH/USP), XXXX hs coined the term Mythodology in Art, an ensemble of research/creative procedures based on myth and ritual that seeks to stimulate the emerging of the artist's intimate drives, in an effort to perfect the diversity of the images chosen among the so-called art-ethnographic experiences. Art-ethnography, a concept also developed by XXXXX, can be translated into an act of weaving together the individuals (artists) and their counterparts (communities). From mythodologial/art-ethnographic experiences the artist has created the performances Joana In Cárcere (2005), Guerreiras (2009) and Homens e caranguejos (2012), developping a third concept: the $f(r) i c t i o n$ actor. This paper focuses on exposing the procedures used by XXXX in the construction of these dramaturgies/performances and is a written version of a talk given at the I Jornada de Pesquisa Mulheres em Cena, which took place in February 2014 at Universidade Estadual de Santa Catarina (UDESC).

Keywords: Art-ethnography; mythodology in Art, F(r)iction Actor.

ISSN: 1414.5731

\footnotetext{
1 Universidade Estadual Paulista (UNESP). Profa Dra. Atriz, performer, dramaturga e diretora. São Paulo (SP). unaluna.unaluna@gmail. com
} 
Quero inaugurar esta minha fala de hoje explicitando que não sou unicamente uma intelectual, sou uma artista, escrevo com o corpo, apaixono-me por fatos, que a princípio não são teatro, dança ou performance. E esta escrita, é uma escrita de mim mesma, um afundamento em minhas questões idiossincráticas e nas questões daqueles que comungam comigo dos processos que vim a orientar durante esses últimos anos.

No sentido de termos um panorama mais íntegro desta trajetória da investigação e compreensão dos conceitos e das práticas que acabei desenvolvendo, faço agora uma retrospectiva poético-temporal. Espero que seja um momento nosso, um compartilhamento, uma história que vocês escutam e aguçam os olhos com imagens e podemos conversar sobre, trocar.

Era dezembro de 2001, em Recife. Eu tive um sonho: uma mulher montada num cavalo, seios nus, uma saia vermelha, quebrando toda uma sorte de correntes. Impulsionada por essa repetida imagem onírica, resolvi produzir uma performance, trouxe à cena uma guerreira. Corporifiquei o que intitulei de mito da Joana d'Arc, desdobrando-o em diversos outros mitos femininos, que deram origem a uma sequência de movimentos de uma performance que, longe da Joana francesa, viria dialogar com a cultura popular pernambucana. Existia um dado de continuidade entre mim e Joana. Entre os anos de 2002 e 2005, Joana serviu de mote à investigação de mestrado intitulada Mito Rasgado; Performance e Cavalo Marinho na Cena In processo (LYRA, 2005) e defendida na UNICAMP-SP. Nessa pesquisa, onde é destrinchada a poética de criação dessa cena, a partir de experiências na linguagem da performance e no espetáculo de Cavalo Marinho, defrontei-me com o trabalho sob a máscara ritual (Cohen, 2007, p. 58), enquanto procedimento de atuação comum ao performer e ao brincante, ambos mediadores dessas expressões cênicas.

Passei a compreender, por meio dessa investigação, que trabalhar sob a máscara ritual significava cenicamente, que o performer ou o brincante ao atuarem, compunham algo que era diferente de sua pessoa do dia-a-dia, mas não vinha a interpretar algo, vinha simbolizar algo em si, rompendo com o advento da interpretação e se aproximando estreitamente da vida. À denominação máscara ritual antes empregada pelo pesquisador Renato Cohen, acresci a terminologia de si mesmo, apontando assim o procedimento de atuação sob a máscara ritual de si mesmo. Em 2005, consolidou-se a performance Joana In Cárcere, como parte da minha dissertação de mestrado... Produzi dramaturgia... Performei... Poetizei...

(CANTO)

"O Mundo estava em guerra, ninguém mais se entendia. Canhões de artilharia davam tiros sobre a terra. Foi ai que na serra tudo se modificou. Quando alguém anunciou, disparado na carreira, nasceu um pé de roseira onde a moça mijou" (Mestre Ambrósio).

(PERFORMO)

Estou sozinha, no alto. No alto, erguida na pequena ermida que construí em meio a um terreiro, entre árvores trançadas em galhos e correntes num só clarão. Do alto vou jogar meu corpo, lavar minhas lágrimas no rio entre chamas, que me preenche inteira, que sou eu. Na terra, vou tocar sons que foram meus, negros sons de largos pés no chão, de imensas ancas, que an- 
seiam parir uma mulher. De menina... Sou negra... Volto a ser. Canto, oro, conto: "Tudo é traçado na terra pela vontade do além. No céu, no mar, na terra e viva Deus e mais ninguém." Conto como negra e negras engolem o rio, lavando as roupas da alma que é minha. Lembranças de beira de estrada, de corredores de rio correndo nos lugarejos de minha terra, de inusitadas luzes que comunicam o mundo em meio a natureza invadida. Memórias que vêm como repentes e surtos de meninos pulando para ver a alegria. É o boi! Eh, boi! Eh, boi! Dança! Dança! Dança! Dança! Silêncio! Escuta! Escuta! Espera! Que vozes são estas? Que sinos são estes? As vozes são como cães que uivam na noite. São como santas. São santas! Talvez seja um sonho. Um dia eu tive um sonho. Parecia que todo o canavial se voltava contra mim. Escuta! Sou santa! "Santa Catarina, dá-me tua voz. Onde estão meus anjos, não os vejo mais! São Miguel arcanjo, dá-me tua paz. Onde estão meus anjos, não os ouço mais." Escuta! Sou santa! Não estou só novamente! Segue-me sombra de mim. Ouço cascos, relinchos e uivos de bicho. Sou tomada em quadris, peles e pêlos, que, felinamente eqüinos, cavalgam-me. Saem de mim, saia, arco e sons de rabeca, sai de mim saia de pernas pintadas, de homem com botas nos estribos. Ouço aboios chorando ao longe? Ou sou eu? Grito! Sou outro corpo, parece-me! Uma força vermelha, uma dor que me move. Selvagem. Guerreira. Quero fogo em mim, batuques, bonecas de maracatu. Avanço! Adiante! Ponho fogo em mim, em sombras e personas, em vestes, véus, partes do que sou para ser outra, ser a mesma, una, uma só luz, depois da passagem. Cavalgo sobre chamas, as chamas que me chamam... Silêncio! Vento, cabelos, lua, fogo adiante, respira, nasceu, nasceu, nasceu...Já estou fora do meu corpo (Lyra, 2005, p. 183).

Junho de 2006. São Paulo. A noite foi cortada ao meio... Tomada de assalto por olhos sem sono, eu pensava na continuidade da investigação de mestrado, defendida em fins de 2005. Não seria mais o universo do Cavalo Marinho. Interessava a lida do performer ou do brincante com a máscara, interessava mais a narrativa imagética do mito. Interessava como o mito era articulado e restaurado pelo rito, pela performance. Como que numa pulsação assombrada, um livro projetou-se na estante do quarto. Um livro escuro de rubras letras: Tejucupapo, História-Teatro-Cinema (Bezerra, 2004). Eu havia recebido de presente durante o mestrado, um dramaturgo pernambucano presenteou-me em meu aniversário, um janeiro de 2005. Na dedicatória, um recado: [...] material bom pra fazer o juízo da gente ferver e se abrir ainda mais, com vontade de criar mais e mais [...]. O livro tratava de um acontecimento no interior de Pernambuco, um episódio banido dos livros escolares: a Batalha de Tejucupapo, onde se deu a primeira participação de mulheres em conflito armado no Brasil. 




Performance Joana Apocalíptica, de Luciana Lyra. Foto: Karla Martins. Agosto de 2013.

Foi entre 1630 e 1654, holandeses estiveram na capitania de Pernambuco com o objetivo de restaurar o comércio do açúcar com os países baixos, proibido pela coroa da Espanha. Uma esquadra, com 64 navios e 3.800 homens, conquistou Olinda e depois Recife. Com a vitória, as forças holandesas foram reforçadas por um efetivo de mais 6.000 homens, enviado da Europa para assegurar a posse da conquista. Como povo guerreiro, Pernambuco resistiu num movimento que chama Insurreição Pernambucana ou Guerra da Luz Divina. Foi neste contexto de combates, mais precisamente em 1646, que aconteceu A Batalha de Tejucupapo. Desguarnecidos em Olinda, cerca de 600 soldados, saídos por mar do Forte Orange, na ilha de Itamaracá, tentaram ocupar Tejucupapo, onde esperavam encontrar a farinha de mandioca e o caju. Mas os estrangeiros foram frustrados em sua intenção porque houve reação da pequena e valente população local, que tendo à frente quatro mulheres - Maria Camarão, Maria Quitéria, Maria Clara e Maria Joaquina - lutou bravamente contra os invasores.

Os parcos registros informam que elas ferveram água em tachos e panelas de barro, acrescentaram pimenta, e escondidas nas trincheiras que haviam cavado, atacavam os holandeses com a mistura jamais esperada por eles. Seus olhos eram os principais alvos, e a surpresa o melhor ataque. A batalha durou horas, mas naquele 24 de abril de 1646, as mulheres guerreiras do Tejucupapo, vilarejo que fica entre Pernambuco e Paraíba, no município de Goiana, saíram vitoriosas.

Março de 1984. Acometida de um nódulo em um dos seios, a auxiliar de enfermagem Luzia Maria da Silva aporta no Recife, onde recebe o apoio dos médicos 
e de uma colega enfermeira, que passou a tranqüilizá-la sobre seu estado, dizendo que "toda mulher de Tejucupapo é uma guerreira" e que, sendo Dona Luzia de lá, precisava ter forças para superar a adversidade. Foi a nova colega que lhe falou, com minúcias sobre as corajosas mulheres tejucupapenses, que haviam expulsado os invasores holandeses no longínquo século XVII, exatamente no local onde ela nascera, crescera, casara e tivera seus filhos.

A descoberta de seu fundamento a fez estabelecer uma promessa a si mesma: a recuperação de sua saúde em troca da restauração da história de Tejucupapo, da sua história. Embora nunca tivesse assistido a um espetáculo cênico "oficial" em toda a sua vida, Dona Luzia arranjava tempo para escrever, dirigir e atuar, criando peças de teatro para propagar os ensinamentos bíblicos. Sua formação artística abraçava as manifestações "oficiosas" do povo, como o Coco, o Pastoril e o Cavalo Marinho, tão presentes e basilares na constituição das sociedades da Mata Norte.

O teatro foi a linguagem que Dona Luzia encontrara para transformar a peleja das mulheres numa história restaurada, que passou a acontecer no último domingo de abril, ano após ano, desde 1993 até os dias de hoje, com o nome de A Batalha das Heroínas, ampliando-se, em 2002, para um evento intitulado A Festa das Heroínas, constituído de shows, feira típica, apresentações de grupos tradicionais e a culminância com o espetáculo teatral.

A peça A Batalha das Heroínas tem como protagonistas as próprias mulheres do lugarejo, "atrizes" recrutadas entre donas-de-casa, servidoras públicas, agricultoras e pescadeiras - como são chamadas aquelas que vivem da maré, catando mariscos e ostras para a venda na sede do distrito. "No teatro, as mulheres trazem à tona as suas próprias vidas" (Bezerra, 2004, p. 64). Durante a Festa/Peça, o que é rústico, pobre e rural, torna-se admirável, guerreiro, utópico, e irrompe em pleno Monte das Trincheiras, antigo lócus da batalha das heroínas de 1646, agora palco da encenação. Em ensaios e apresentação, no decorrer de todo mês de abril, as mulheres simples tomam à frente do combate das heroínas ancestrais, alimentando-se de suas máscaras, e oferecendo a essas mesmas máscaras, pelo caminho inverso, a possibilidade da restauração pela experiência performática. As máscaras das heroínas antepassadas pareciam abalar um eu das heroínas atuais, abriam-nas para o mundo e, no mundo, a abertura para o outro.

Com a descoberta das mulheres de Tejucupapo, percebi ressonâncias entre a cena de Joana e o espetáculo A Batalha das Heroínas. Essa aproximação constelar parecia acontecer por intermédio de três aspectos: um mesmo mito fundava ambas as encenações; as experiências performáticas articulavam passado e presente por meio de imagens; as máscaras das atuantes advinham de um campo eminentemente autoral, eram autorreferentes. Impulsionada pela percepção das estreitas relações entre minha poética e o imaginário tejucupapense, parti, no ano de 2007, para o aprofundamento da máscara ritual da guerreira Joana. Junto à comunidade, iniciei minha investigação de Doutorado em Artes Cênicas (IA/UNICAMP), interessada em perseguir as possíveis interfaces entre o encaminhamento de meus trabalhos artísticos e a montagem teatral deste coletivo da Mata Norte, convergindo, especificamente, para o modo como as mulheres atuam no espetáculo $A$ Batalha das Heroínas, no que tange às máscaras e aos vetores simbólicos que as animam na expressão performática. 
Nesse mesmo período, além de estabelecer contato inicial com bibliografia acerca de estudos sobre a Antropologia do Imaginário em disciplina do doutorado, integrei minha pesquisa ao projeto temático do Núcleo de Antropologia, Performance e Drama - NAPEDRA, intitulado "Antropologia da Performance: Drama, Estética e Ritual". Por essas experiências, a investigação afirmou-se como processo interseccional entre a Antropologia e as Artes Cênicas, fomentando uma trança, onde os fenômenos da performance e do imaginário desvelam-se como vértices do processo criativo em artes. Desenvolvida entre os anos de 2007 e 2011, a investigação passou a representar um processo de confluência de campos afins, que ampliou o foco em relação aos meus estudos de Especialização em Ensino da História das Artes e das Religiões (UFRPE/2002) e Mestrado em Artes (UNICAMP/2005), ambos orbitando em torno de procedimentos pedagógicos para criação de poéticas cênicas, com base em: memória, identidade, gênero, manifestações populares, performance e mito.

Nos dois primeiros anos, a pesquisa realizou-se, fundamentalmente, por meio de minha atuação na comunidade, enquanto uma observadora, que aos poucos alçou o patamar de participante familiar nas ações coletivas, elaborando reflexões e construindo pontes entre a experiência em campo, as disciplinas acadêmicas e as leituras da bibliografia selecionada. Em fins do segundo ano, porém, principiou-se o processo de criação do espetáculo Guerreiras, desenvolvido sob minha direção, com um grupo de artistas-pesquisadores, em São Paulo e no Recife, tendo por base principal o universo das mulheres tejucupapenses. Além da inspiração nas heroínas da Zona da Mata, deusas de todos os tempos fomentaram a montagem de Guerreiras, assim como uma camada predominantemente pessoal concluiu um tripé de estímulos à criação, que estreou em abril de 2009, sendo apresentada no Recife, em Tejucupapo e São Paulo.



Espetáculo Guerreiras, encenação e dramaturgia de Luciana Lyra.

Em cena: Cris Rocha, Katia Daher, Luciana Lyra, Simone Evaristo e Viviane Madu. Foto: Val Lima. Janeiro de 2010. 
Com o lançamento do espetáculo sob minha direção, o jogo entre o grupo por mim orientado, que denomino guerreiras, e as mulheres de Tejucupapo, que denomino heroínas, tornou-se estranho, passou de não somente complementar e familiar, mas também concorrente e antagonista. $O$ resultado ruidoso que teve como mote a encenação de Guerreiras no embate com a encenação de $A$ Batalha das Heroínas aponta a complexa trama entre esses dois dramas estéticos, mediados por uma mesma máscara-base, impulsionada por um mesmo mito-guia. Espetáculos como $A$ Batalha das Heroínas e Guerreiras, pelas suas origens e constituições, são favoráveis para o surgimento de símbolos poderosos, cuja multivocalidade reúne elementos contrastivos que energizam a comunicação. Como campo para fulguração expressiva capaz de completar uma experiência, a performance constitui uma forma de linguagem e um gênero de ação simbólica (Turner, 1982), por meio dela o suprimido se revela. Algo acontece no nível da percepção: imagens do passado são evocadas de forma aguda, emoções são revividas, o passado e o presente são presentificados, criando uma nova rede de significação.

Espetáculos como A Batalha das Heroínas e Guerreiras, a personificação das personas não equivale à encarnação de uma máscara ficcional ou à representação de um personagem, mas sucessivas metamorfoses, estando aberto às atuantes sair de sua máscara, reassumindo facilmente sua própria personalidade social e, levando, concomitantemente a máscara como impulso para vida cotidiana. O processo de atuação, dessa perspectiva, estava calcado na ritualização das idiossincrasias das atuantes, no desenvolvimento de suas habilidades pessoais e sociais, em detrimento da interpretação de qualquer papel. Sobre as heroínas, diz Carlos Carvalho, diretor de teatro de Pernambuco:

Ali se vê que o teatro desempenha um papel social e serve como elemento de educação. O teatro de Tejucupapo é fundamental para o auto-conhecimento daquela sociedade. Ali, eles estão falando das próprias vidas. É o cidadão-artista dramatizando sua própria história (apud Bezerra, 2004, p. 64).

Ao vivenciar uma guerreira antepassada em $A$ Batalha das Heroínas, supõe-se assim que a atuante não é o personagem, mas não não o personagem. Também não é ela mesma, mas não não ele mesma. Nos interstícios entre as atuantes e as personas, os corpos adentram em constantes fluxos e metamorfoses, gerando-se aí a possibilidade de uma ação social para a mudança, no lócus alternado entre o eu e as alteridades. Enquanto experiência performática ou estética, $A$ Batalha das Heroínas provoca mais do que um simples espelhamento do real. Se como "espelhos mágicos" dramas estéticos e rituais espelham a vida social, a recíproca também é verdadeira: dramas sociais espelham formas estéticas. Pessoas, que se revelam como personas, performatizam a suas vidas (Turner apud Dawsey, 2000). Partindo dessa proposição, as atuantes sob a máscara ritual geram um estado de $f(r)$ icção, de atrito e desconstrução que é dialeticamente inverso ao da ficção (fictio ou algo modelado, construído) (Dawsey, 2000). Nessa perspectiva, a máscara que modela também desconstrói, ela produz uma alegre transformação e relatividade das coisas... 
roínas de lá, não gosto quando pingam limão nas minhas profundezas e fazem com que eu me contorça toda. Os fatos da vida são o limão na ostra? Será que a ostra dorme? Creio que não! Ela se contorce de dor, mas aos poucos se vê livre. Não estou brincando. Estou grave. Porque estou livre. Quando nasço, fico livre. Esta é a base de minha tragédia. Eu nasci, tive assim esse começo. Hoje lembro que as filhas da noite também nasceram em Tejucupapo, como minha mãe, avós, madrinhas, tias, as joanas, minha Joana. Se houver uma guerra, a culpa é delas, a culpa é minha. Tejucupapo desemboca na rua onde vivi em Recife (Lyra, 2013, p. 15 , inédito).

O palco das guerreiras e heroínas mostrava-se como um amplo jogo de espelhos estilhaçados, lugar de exibição de identidades e construção de autoimagens. Espaço de transformação. Enquanto nós éramos atravessadas pelas narrativas e vida daquelas mulheres, transformando-nos, elas, por sua vez, foram por nós afetadas, tomando às "rédeas" de seu teatro. Uma oposição, uma ruptura transformadora! Em Tejucupapo tudo se imbricava na expressão da cena das heroínas ou das guerreiras. As performances eram a culminância do processo que intitulei artetnográfico, provocando a transformação dos performers e das suas relações. Ao levar a público suas personas, guerreiras e heroínas, atrizes e mulheres da comunidade revelavam o que são na vida, as performances eram oportunidades de mostrar sua própria humanidade, enquanto a Artetnografia era a operação de entrelaçamento destes eus dos artistas à alteridade (comunidade).

Sem ignorar as transformações que a performance efetua nos performers de forma individual, gostaria de perceber a produção de Guerreiras aqui, como Turner, como "finalização de uma experiência coletiva", que chamei de experiência artetnográfica. Essa manipulação de expectativas, medos, vaidades e do prazer de construir e apresentar as performances, trouxe à tona para Guerreiras e Heroínas, um intenso aprendizado sentimental e a possibilidade da tramarem-se enquanto seres e artistas. Foi da experiência artetnográfica com a comunidade de Tejucupapo que surgiu Guerreiras. Podemos assim traduzir a Artetnografia como uma trama complexa concebida do contato entre artistas e comunidade, entre eus e alteridades.

Da Artetnografia vislumbrou-se um modus operandi de criação, a Mitodologia em Arte, por meio da qual o artista partícipe do processo cênico vincula-se intimamente à produção de sentido da criação. Esse modus operandi não se constitui uma pré-fixação incondicional de práticas, mas procedimentos de cunhos ritualísticos e míticos, que possam fazer eclodir pulsões pessoais e, concomitantemente, universais dos artistas. Esse complexo é um caminho em que o artista aperfeiçoa o pluralismo das imagens colhidas no seu trajeto antropológico, a partir de suas experiências artetnográficas.

Meses após a última jornada com as Guerreiras... Em 2010. Estava em Recife novamente... E pleno era o sol do dia. Vi estampada a inscrição: "Sonhos distantes, em barcos ausentes, velozes, ondeantes. Sonhos distantes, paisagens vivas, longe." Era julho, e a escritura poética de autoria de Josué de Castro estampada na parede do Centro Josué de Castro, na capital pernambucana. Josué de Castro, brasileiro, pernambucano, cidadão do mundo, cientista, homem de múltiplos saberes, morto no exílio, vítima de um regime que corroeu ideias sobre igualdade e liberdade social. Naquele dia, entendi que Josué havia entrado em minha vida definitivamente, pois à minha frente estava um homem movido pelos sonhos, faminto por dar asas a uma geografia eminentemente 
humana. Digo, entrou definitivamente em minha vida, por que, antes, em janeiro desse mesmo ano ainda no fogo da pesquisa de doutorado, as atrizes do Coletivo Cênico Joanas Incendeiam, provenientes do curso de Artes Cênicas da UNESP, haviam me procurado na intenção de que pudéssemos firmar uma parceria para montagem de Homens e Caranguejos, único romance de Castro, datado de 1967.

Instigada com o projeto, lancei uma contraproposta às atrizes: traçar uma linha contínua entre a Aldeia Teimosa, comunidade ficcional inventada por Castro em seu romance, e comunidades atuais, adensando o conceito da Artetnografia, já cunhado em meu doutorado, quando de minha pesquisa com as mulheres heroínas da comunidade de Tejucupapo. Guiadas pela Artetnografia, caímos em campo na llha de Deus, no coração da cidade do Recife, e do Boqueirão, em São Paulo, buscando descortinar a atualidade da obra de Josué. A intenção não se configurava na adaptação literal do romance para o teatro, mas o entrecruzamento entre a experiência do cientista, poetizada em sua obra, com a nossa experiência nestas comunidades periféricas.

São Paulo, período compreendido entre julho a dezembro de 2012. Reflito... De certa forma, o auge da ida aos campos, o desdobramento nos laboratórios mitodológicos em sala de ensaio para montagem e as apresentações de Homens e Caranguejos, foi perceber como a Artetnografia configurava-se na experiência. Como as cores, matérias, tons e discursos nos preenchiam poeticamente, dialogavam com o livro-base de nossa encenação, transbordavam na cena. Realidade e ficção entraram em atrito, os anos sessenta do último século decorrido e relatado no livro estavam se fazendo naquelas experiências. Imagens do passado de um Castro romanceado se articulavam a um presente, eminentemente real e, a um só passo, performático.

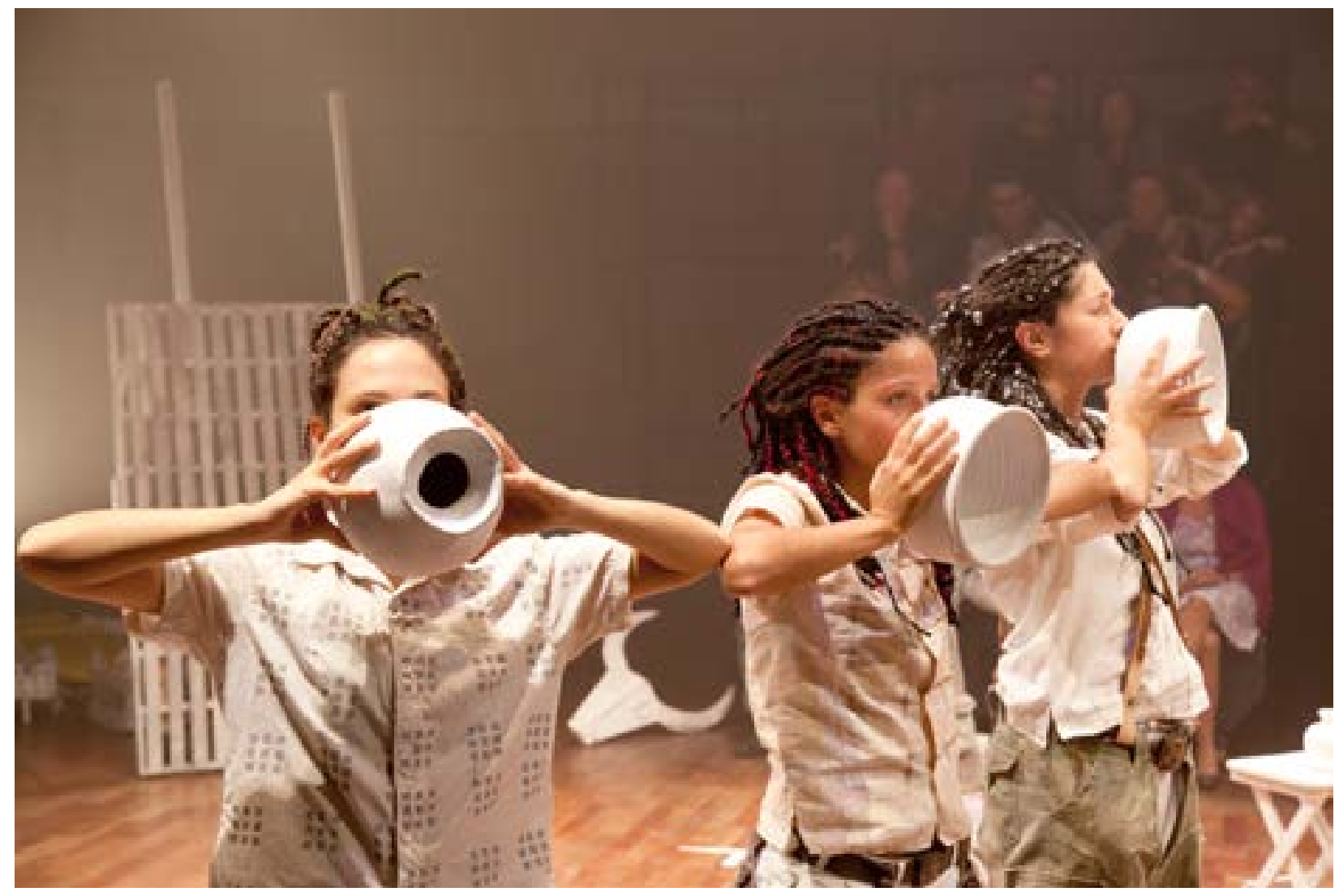

Espetáculo Homens e Caranguejos, encenação e dramaturgia de Luciana Lyra.

Com Coletivo cênico Joanas Incendeiam (Beatriz Marsiglia, Camila Andrade e Letícia Leonardi). Foto: Alícia Peres. Maio de 2012. 
As narrativas acerca do descaso social e sobre a permanente luta política pela natureza, pela sobrevivência, pela identidade, capturadas em campo, estavam presentes na poética de cada experimento cênico, que desaguou na dramaturgia/encenação. Como que regidas pelo mito de Hermes, as artetnógrafas transitaram entre dois mundos: o eu e a comunidade, apresentando-se, diante mão, como performers e a pesquisa, tal como uma performance, como vertente de expansão das possibilidades do processo criativo entre o eu e o outro.

São Paulo, junho de 2013, em contínua reflexão... A experiência vivida em campo em Guerreiras e Homens e Caranguejos pressupõe a atuação num plano liminar entre o real e o ficcional, a atuação de um ator de f(r)icção, um ator-cartógrafo, que vai traçando paisagens na relação com "o outro". Longe de seguir uma reta de fatos, essa cartografia revela-se em pedaços, em justaposições instáveis, onde a realidade não é um dado somente, a realidade transcende, atingindo a subjetividade dos sujeitos. Desta trança artetnográfica urdida entre artistas e comunidade, trança esta eminentemente política e lúdica, é que foram fiados os espetáculos. Tais investidas cênicas manifestaram-se na trama entre: experiências em comunidades, laboratórios de ensaio e construção de dramaturgia/encenação, arregimentando um complexo de procedimentos da Mitodologia em Arte, um complexo, que parte do si mesmo (o artista) para galgar o outro (a comunidade), que propõe uma arte de existência, destacando-a num patamar não só estético, mas ontológico, capaz de investigar a natureza do agir e dos modos de ser do artista, de desvelar suas potencialidades mais altas.

Com inspiração primeira na ideia de Mitodologia, cunhada por Gilbert Durand (1990), a Mitodologia em Arte, lida com forças pessoais que movem o atuante na relação consigo mesmo e com o campo, num processo contínuo de retroalimentação. Da perspectiva durandiana e seus predecessores estudiosos do imaginário, entendemos que o ser humano tem uma vocação mitológica e ritualística, performática, como também aponta Victor Turner (1974) em seus estudos sobre a Antropologia da Experiência. Há assim uma necessidade vital da imagem e da experiência, uma herança de mitologias, que se põe à prova pelo rito. Desse ponto de vista, o símbolo permite estabelecer o acordo entre o eu e o mundo.

Do viés da Antropologia da Experiência, apontamos uma pedagogia calcada metodologicamente na performance, nas emergências do extraordinário, onde a relação ensino-aprendizagem dá-se à semelhança de relações musicais harmônicas, incluindo também ruídos e tensões da experiência do corpo em contínuo processo social. Podemos afirmar que Turner preconiza uma Pedagogia das Margens ou, como o próprio aponta, uma Pedagogia da Liminaridade (1974, p. 129), procurando delinear a performance como metáfora e método, e sugerindo que o corpo dos atuantes aderem constantemente às experiências vividas em sociedade, ou seja, está sempre em estado de aprendizado. A partir dessa ideia entende-se o corpo como lócus performático do jogo ritual, sendo a performance o espaço de materialização da expressão que vai além da mera comunicação de significados, dando vazão aos ruídos gerados da relação ensino-aprendizagem.

A Mitodologia em Arte permite ao artista viver na pluralidade, fomentando o indivíduo na sua abertura para o imaginário e para a performance que, por si, são es- 
paços políticos, de transgressão e de ruptura. Abrir-se para esses espaços é abrir-se aos espaços da invenção e da criação. No contato com o imaginário elaboramos o ato de ver o que hoje nos cativa e provoca, nossa máscara, ligamo-nos à raiz mesma do fenômeno performático e suas possibilidades de re-conhecimento humano, relacionando-o ao trajeto da cultura, por meio da Artetnografia.

A Artenografia é pressuposto fundamental à Mitodologia e se desvela justamente no trânsito entre o eu e a alteridade, do artista ao meio. Fundada sob o mito de Hermes, e afetada da perspectiva etnográfica instável exercitada pela Antropologia da Performance, a Artetnografia busca uma orientação, um sentido, um caminho a ser percorrido através da poética, da politeísmo e das questões que estão nas profundezas de nossa alma individual e coletiva, os fragmentos mais estranhos e refratários ao entendimento. Mais do que as questões acessadas pela leitura direta do nosso intelecto ante a comunidade, o paradigma artetnógrafico requer uma pesquisa indireta que busca construir elos entre os fenômenos, de modo a compreendê-los como estando co-implicados num movimento sempre provisório entre artista e comunidade, entre ser e cosmos, em ato de risco, nos lugares mais ermos, onde o outro se apresenta em toda a sua estranheza e o passado se articula ao presente. Como aponta Benjamin em destaque no texto de Dawsey: "Articular historicamente o passado não significa conhecê-lo 'como ele de fato foi'. Significa apropriar-se de uma reminiscência, tal como ela relampeja no momento de um perigo" (Benjamin apud Dawsey, 2005, p. 224-225).

A ideia da jornada artetnográfica não é capturar uma realidade para dramatizá - la, dramatizar dramas sociais e políticos. Também não é elaborar modos de dramatizar observações e argumentos sobre a vida pessoal, social e cultural, nem ocupa-se de representar literalmente fontes da realidade sociocultural. A Artetnografia constitui-se como um operador que promove contaminação entre artistas e comunidades. Sendo que essas comunidades são delimitadas, a partir das dinâmicas pessoais dos artistas no processo de criação, não se desdobra numa forma de teatro que trabalha sobre e com membros de uma determinada comunidade, constitui um modo de apreensão de artistas em comunidades que, por sua vez, são delimitadas em função da demanda particular de cada grupo artístico trabalhado.

Numa dialogia, o processo artetnográfico confere poder a todos os interlocutores envolvidos nos processos, pela via poética, performática. A Arternografia confere um poder à imaginação de um ethos coletivo comum, capaz de dinamizar, reforçar ou mesmo romper laços de comunhão, onde grupos acabam por reconstituir suas identidades experienciando histórias sobre si mesmo, numa espécie de autobiografia coletiva, que parte, necessariamente, de ecos e pulsões particulares dos artistas. É na dramaturgia/encenação que a Artetnografia encontra o lugar privilegiado, na evocação de universos multivocais e fragmentários, próprios da performance, que não enfatiza a escrita como principal mediador de significados. Naturalmente, entendemos dramaturgia/encenação enquanto binômio indissociável, como discorro, em tese de doutoramento, acerca do processo de criação de Guerreiras:

$\mathrm{Na}$ encenação havia efetivamente a materialização da encruzilhada proposta pela dramaturgia, a dramaturgia por sua vez, era gerada a partir da encruzilhada das ações performatizadas. Como uróboros, o processo traduzia-se sob o signo conti- 
nuidade entre dramaturgia e encenação, da autofecundação. Guerreiras traduziase num texto performativo, ou seja, aquele que é gerado pela performance, ao mesmo tempo proporcionando-a, criado nela (Lyra, 2011, p. 152).

No trânsito entre o campo artetnográfico, os laboratórios mitodológicos de criação e a cena, somos transformados e transportados, como diria Schechner (1985), reafirma-se um estado de subjuntividade. Assim, o artetnógrafo, ator de $f(r)$ icção, longe de entender o outro como fonte de criação artística, que jorra incessante no estímulo à mágica inspiração, absorve-o como espelho d'água, que vai ao fundo e às margens, entendendo-se todos os sujeitos como partes de um processo ruidoso, onde eu e outros misturam-se alquimicamente.

Fevereiro de 2014. Florianópolis. Como disse, não sou simplesmente uma intelectual, sou uma artista, escrevo com o corpo, apaixono-me por fatos, que a princípio não são teatro, nem dança, nem performance. Sonhos e situações que produzem uma escrita de mim mesma, um afundamento em minhas questões idiossincráticas. Acontece que só escrevo o que sinto necessário à minha sobrevivência, sou amadora nesse sentido, amo, afeto-me. Os fatos imprimem-se como tatuagem. Eu não inventei Joana, as mulheres de Tejucupapo, homens e caranguejos, eles forçaram dentro de mim sua existência, viraram poética cênica, transmutaram-se, foram das margens às margens, borraram-se e foram ao fundo.

\section{Referências}

BEZERRA, Cláudio (ORG). Tejucupapo, História-Teatro-Cinema. Recife: Bagaço, 2004.

COHEN, Renato. Performance como Linguagem - Criação de um espaço-tempo de experimentação. São Paulo: Perspectiva, 2007.

DAWSEY, John Cowart. Nossa Senhora Aparecida e a mulher-lobisomem: Benjamin, Brecht e o teatro dramático na antropologia. São Paulo. Revista de Antropologia, 2(1):85-103, 2000.

O teatro dos bóias-frias: repensando a antropologia da performance. São Paulo: Horizontes antropológicos, 24:15-34, 2005.

Victor Turner e a antropologia da experiência. São Paulo: Cadernos de Campo, 13:163-176, 2005.

DURAND, Gilbert. Mito, símbolo e mitodologia. Lisboa: Editorial Presença,1990.

LYRA, Luciana de Fátima Rocha Pereira de. Livro de artista; Homens e Caranguejos. São Paulo: Inédito, 2013.

Da Artetnografia: migração da máscara mangue em duas experiências performáticas. Relatório (Pós doutorado em Antropologia), FFLCH, Univer- 
sidade de São Paulo (USP), São Paulo-SP, 2013.

. Guerreiras e Heroínas em performance: Da artetnografia à Mitodologia em Artes Cênicas. 2010. Tese (Doutorado em Artes em Artes Cênicas), Instituto de Artes, Universidade Estadual de Campinas (UNICAMP), Campinas-SP, 2011.

Guerreiras; texto teatral e trilha sonora original. Recife: Bras-

color Editora, 2010.

Mito Rasgado; Performance e Cavalo Marinho na cena in processo. 2005. Dissertação (Mestrado em Artes), Instituto de Artes. Universidade Estadual de Campinas (UNICAMP), Campinas-SP, 2005.

Formação humana e estética para contemporaneidade - Sentido do ensino-aprendizagem do teatro dentro e fora da escola. 2003. Monografia (Especialização em Ensino da História das Artes e das Religiões) - Departamento de História, Universidade Federal Rural de Pernambuco, Recife-PE, 2003.

ROLNIK, Suely. Cartografia Sentimental. São Paulo: Salima: UFRGS, 2007.

SCHECHNER, Richard. Between Theater and Antropology. Philadelphia: University of Pennsylvania Press, 1985.

TURNER, Victor. From Ritual to Theatre: The Human Seriousness of Play. New York: PAJ, 1982.

1974.

O processo ritual; estrutura e antiestrutura. Petrópolis: vozes,

Recebido em 15/05/2014

Aprovado em 26/06/2014 